\title{
PENDAMPINGAN PASTORAL BAGI NARAPIDANA YANG AKAN BERAKHIR MASA TAHANAN (TINJAUAN ASPEK SOSIAL)
}

\author{
Alvin Koswanto \\ STT Ekumene Jakarta \\ Mal Artha Gading Lt. 3, Jl. Artha Gading Selatan No 1 \\ Kelapa Gading, Jakarta Utara 14240 \\ Email: alvin.koswanto@sttekumene.ac.id
}

\begin{abstract}
ABSTRAK
Adanya stigma masyarakat terhadap mantan narapidana merupakan fenomena yang masih kerap terjadi ketika narapidana keluar dari Lembaga Pemasyarakatan. Penolakan kehadiran mereka membuat mantan narapidana enggan bersosialisasi dengan normal. Penelitian ini bermaksud untuk mengetahui bagaimana peran Lembaga Pemasyarakatan Salemba dalam mempersiapkan narapidana menghadapi akhir masa tahanannya ditinjau dari aspek sosial. Metode yang digunakan dalam penelitian ini adalah kualitatif. Dalam melakukan penelitian ini, peneliti datang ke Lembaga Pemasyarakatan Salemba untuk memperoleh data-data yang dibutuhkan. Peneliti melakukan wawancara terhadap tiga narasumber, yaitu Pembina Kerohanian Kristen, beberapa narapidana Kristen yang telah mengikuti proses pendampingan di Lembaga Pemasyarakatan tersebut, dan yayasan YASINDO, dimana yayasan tersebut menerima mantan narapidana sebelum terhisap di masyarakat. Hasil dari penelitian ini, didapati aspek pembinaan sosial belum dapat menolong narapidana untuk kembali hidup di masyarakat luas. Kekuatiran atau ketakutan masih dimiliki oleh para narapidana yang akan selesai masa tahanannya. Hal ini dikarenakan kurangnya fasilitas waktu untuk mengikuti pembinaan tersebut.
\end{abstract}

Kata Kunci: Narapidana; Pendampingan Pastoral; Lembaga Pemasyarakatan; Sosial.

\section{ABSTRACT}

The existence of a community stigma against ex-convicts is a phenomenon that still often occurs when prisoners leave the correctional institution. Denial of their presence makes ex-inmates reluctant to socialize normally. This study intends to determine how the role of the Salemba Penitentiary in preparing prisoners to face the end of their detention in terms of social aspects. The method used in this research is qualitative. In conducting this research, researchers came to the Salemba Penitentiary to obtain the required data. Researchers conducted interviews with three sources, namely Christian Spiritual Guidance, several Christian prisoners who have participated in the assistance process at the Correctional Institution, and the YASINDO foundation, where the foundation accepts ex-convicts before being exploited in society. The results of this study, it was found that the aspect of social development has not been able to help inmates to return to life in the wider community. 
Prisoners who are about to finish their detention still have worry or fear. This is due to the lack of time facilities to participate in the coaching.

Keywords: Prisoners; Pastoral Assistance; Correctional Institution; Social.

\section{PENDAHULUAN}

Perubahan sosial di Indonesia dapat dikatakan sedang mengalami kemunduran. Hal ini dapat dilihat dari meningkatnya tindakan masyarakat yang melawan hukum atau melakukan tindakan kriminalitas. Fenomena ini terjadi karena adanya pergeseran tatanan budaya, pengabaian atas nilai kejujuran, menipisnya akan budaya malu, disorientasi atas kehormatan, berkembangnya gaya hidup yang hedonisme, pengabaian hak-hak yang dimiliki oleh manusia, hilangnya akan kepercayaan kepada hukum, dan kepatuhan terhadap hukum yang makin merosot (Mawardi, 2015).

Salah satu upaya yang dilakukan pemerintah untuk menanggulangi tindak kejahatan tersebut adalah dengan memberikan sanksi bagi pelaku kejahatan. Sanksi tersebut tergantung dari putusan pengadilan terhadap kejahatan yang dilakukan. Upaya ini tentunya bukan bermaksud untuk membinasakan si pelaku kejahatan, namun bertujuan untuk memberi efek jera, membuat pelaku kejahatan belajar tertib hukum dan tidak mengulangi kejahatannya kembali. Upaya ini tidak terlepas dari adanya kegiatan pembinaan dalam Lembaga Pemasyarakatan.

Ketika menjalani masa hukuman di Lembaga Pemasyarakatan, narapidana tidak hanya mengisi waktu mereka dengan menganggur dan menunggu masa tahanannya selesai. Ada serangkaian kegiatan yang diberikan oleh petugas penjara tersebut yang harus dilakukan oleh seluruh narapidana.(Sanusi, 2019) Salah satunya adalah para narapidana wajib mengikuti pembimbingan keterampilan. Pembimbingan tersebut dilakukan untuk membangkitkan semangat narapidana yang mentalnya pernah rusak, sehingga selepas dari penjara mereka memiliki keterampilan kerja dan tidak akan kembali ke profesi sebagai penjahat dan dapat kembali ke dalam lingkungan masyarakat menjadi warga yang baik dan bertanggung jawab (Astuti, 2011).

Para narapidana yang telah bertahun-tahun berada dalam penjara, tentu sangat mengharapkan masa tahanannya cepat selesai. Ada sebuah kerinduan untuk berjumpa kembali dengan keluarga, kerabat, dan sebagainya yang telah lama tidak mereka jumpai ketika berada dalam penjara. Namun, ternyata para narapidana tersebut justru 
mengalami kecemasan dan kegelisahan ketika masa tahanannya akan selesai.

Kecemasan dan kegelisahan tersebut adalah apakah setelah keluar dari penjara nanti, mereka akan diterima kembali dalam lingkungan keluarga dan masyarakat sekitar. Stigma apa yang masyarakat akan berikan kepada mereka sebagai mantan narapidana. Mereka takut apakah nanti mampu mencari pekerjaan atau membuka lapangan pekerjaan sendiri untuk mencukupi kebutuhan hidupnya dengan riwayat pernah masuk penjara, dan sebagainya.

Melihat fenomena yang terjadi tersebut, maka penelitian ini dilakukan untuk (1) mengetahui bagaimana peran Lembaga Pemasyarakatan Salemba Kelas IIA dalam mempersiapkan narapidana menghadapi akhir masa tahanan, (2) mengetahui peran pendampingan pastoral bagi narapidana yang akan berakhir masa tahanannya ditinjau dari aspek sosial.

\section{METODE}

Peneliti menggunakan metode kualitatif. Pengumpulan data dalam penelitian ini bersifat interaktif dengan analisis data, pengumpulan data merupakan bagian integral dari kegiatan analisis data.(Zaluchu, 2020) Untuk memperoleh data-data yang dibutuhkan, peneliti mendatangi langsung ke Lembaga Pemasyarakatan Salemba. Peneliti melakukan wawancara terhadap pembina narapidana Kristen untuk memperoleh informasi mengenai visi, misi, dan harapan Lembaga Pemasyarakatan tersebut terhadap narapidana Kristen. Peneliti juga melakukan wawancara terhadap beberapa narapidana Kristen yang telah mengikuti proses pendampingan tersebut untuk mendapatkan hasil dari proses pendampingan yang telah dilaksanakan selama ini.

Dalam melakukan pengumpulan data, peneliti menggunakan teknik wawancara tidak terstruktur. Kemudian, untuk melakukan validasi dan kredibilitas data, peneliti melakukan wawancara terhadap tiga sumber, yaitu Pembina Kerohanian Kristen, narapidana Kristen yang masih berada di Lembaga Pemasyarakatan Kristen, dan narapidana yang akan berakhir masa tahanannya.

Lokasi yang peneliti gunakan untuk melakukan penelitian adalah Lembaga Pemasyarakatan Salemba kelas IIA yang beralamatkan di Jalan Percetakan Negara No. 88A, RT/RW 12/4, Rawasari, Cempaka Putih, Kota Jakarta Pusat, 10570. Dalam 
penelitian ini, yang menjadi narasumber adalah Pembina Kristen, narapidana Kristen dan koordinator pembina Yayasan Anugrah Sejahtera Indonesia (YASINDO).

Dalam melakukan penelitian ini, peneliti membutuhkan waktu yang cukup panjang. Dari mulai melakukan pengamatan awal, proses penelitian, hingga penulisan laporan. Adapun waktu yang dibutuhkan peneliti dapat dilihat dalam tabel berikut ini:

Tabel 1.

\begin{tabular}{|c|l|c|c|c|c|c|}
\hline \multirow{2}{*}{ No } & \multicolumn{1}{|c|}{ Kegiatan } & \multicolumn{5}{|c|}{ Bulan } \\
\cline { 3 - 7 } & & Jan & Feb & Mar & Apr & Mei \\
\hline 1 & $\begin{array}{l}\text { Pengumpulan data (Observasi, } \\
\text { Wawancara, Dokumentasi) }\end{array}$ & $\boldsymbol{\nabla}$ & $\boldsymbol{\nabla}$ & $\boldsymbol{\nabla}$ & & \\
\hline 2 & Analisa data & & & & & \\
\hline 3 & Penulisan laporan & & & & & $\boldsymbol{\nabla}$ \\
\hline
\end{tabular}

\section{HASIL DAN PEMBAHASAN}

\section{Pendampingan Pastoral}

Pendampingan Pastoral merupakan penggabungan dua kata yang mempunyai makna pelayanan, yaitu kata pendampingan dan kata pastoral (Van, 2017).

Pendampingan merupakan kegiatan kemitraan, bahu-membahu, menemani, dan berbagi dengan tujuan saling menumbuhkan dan mengutuhkan (Van, 2017). Dalam mencapai keberhasilan dari proses pendampingan ini, orang yang didampingi atau konseli adalah pihak penentu. Artinya, berhasil atau tidaknya proses pendampingan tidak ditentukan oleh orang yang mendampingi atau konselor, melainkan orang yang didampingi tersebut.(Hendri Wijayatsih, 2011)

Engel dalam bukunya mengutip pendapat Kartadinata, menjelaskan bahwa pendampingan merupakan suatu proses pendidikan kepada individu untuk mencapai tingkat kemandirian dan perkembangan diri sepanjang hayat (lifelong education) (Engel, 2016). Karena pendampingan ini bersifat proses pendidikan, maka orang yang menjadi pendamping harus bersedia membimbing, merawat, memelihara, melindungi, menolong, dan memperbaiki relasi yang terputus dengan diri sendiri, orang lain, dan Allah. Hal ini berhubungan dengan fungsi pastoral yang lebih menunjukkan tugas bagi seorang gembala atau pendeta.(Nugroho, 2017; Sriulina, 2017) 
Clinebell berpendapat bahwa pendampingan pastoral merupakan suatu pelayanan pertolongan dan penyembuhan dari gereja, baik secara individu maupun kelompok sehingga dapat bertumbuh dalam proses kehidupannya di masyarakat (Engel, 2016). Dengan kata lain, pendampingan pastoral ini dilakukan secara sengaja terhadap anggota gereja yang sedang mengalami permasalahan atau pergumulan hidup. Dari beberapa pendapat tersebut, maka dapat disimpulkan bahwa pendampingan pastoral merupakan bentuk pelayanan pastoral yang diberikan kepada seseorang yang sedang mengalami permasalahan dalam hidupnya, dengan harapan ia mampu memperbaiki hidupnya sendiri, hubungannya dengan Allah dan sesama.

Ada beberapa kegunaan atau manfaat dari melakukan pendampingan pastoral, yaitu: Fungsi Membimbing (Guiding). Pembimbing melakukan bimbingan terhadap konseli dalam memilih atau mengambil sebuah keputusan, serta menginformasikan resiko atau kemungkinan yang akan terjadi berkaitan dengan keputusan yang akan diambil bagi kehidupannya di masa yang akan datang. Fungsi mendamaikan/memperbaiki hubungan (Reconcilling). Pada dasarnya manusia merupakan makhluk sosial yang membutuhkan relasi atau hubungan dengan orang lain. Dan yang menjadi salah satu kebutuhan manusia adalah hidup dan merasa aman bersama dengan orang-orang yang dekat dengan dia, seperti suami/istri, anak-anak, mertua, menantu, dsb. Oleh karena itu, salah satu fungsi dari pendampingan pastoral dalam hal ini adalah berperan sebagai perantara untuk memperbaiki hubungan yang rusak dan terganggu (Van, 2017).

Fungsi menopang/menyokong (Sustaining). Fungsi ini sangat tepat ketika konselor diperhadapkan dengan konseli yang mengalami masalah krisis yang mendalam, seperti kehilangan, kematian orang yang dikasihi, dukacita, dsb. Topangan/sokongan berupa kehadiran dan sapaan yang meneduhkan dan terbuka, akan mengurangi penderitaan mereka (Van, 2017). Dengan adanya topangan atau sokongan yang diberikan, maka akan mengurangi penderitaan yang dialami oleh konseli. Fungsi menyembuhkan (Healing). Fungsi menyembuhkan disini sangat penting dilakukan kepada konseli yang mengalami tekanan emosi namun tidak pernah diungkapkan dengan kata-kata atau perasaan seperti menangis, dan sebagainya. Fungsi ini bertujuan untuk mengatasi kerusakan yang dialami seseorang dengan cara memperbaiki orang 
tersebut menuju keutuhan dan membimbing orang tersebut mencapai keadaan yang lebih maju dari keadaan yang sebelumnya (Clebsch \& Jaekle, 1994).

Fungsi mengasuh (Nurturing). Fungsi ini membantu konselor dalam melihat kira-kira potensi apa saja yang dimiliki oleh konseli, sehingga menjadi kekuatan yang dapat digunakan untuk tetap melanjutkan kehidupannya. Artinya konselor menolong konseli untuk meninggalkan setiap permasalahan yang telah dialaminya dan menjalani kehidupan di masa yang akan datang. Konselor perlu menolong konseli untuk berkembang.

Dalam melakukan pendampingan, seorang konselor harus mengetahui tujuan dari pelayanan pendampingan pastoral terhadap orang yang didampinginya tersebut. Beberapa tujuan dari dilakukannya pendampingan pastoral terhadap konseli, yaitu (Wiryasaputra \& Handayani, 2012): Berubah menuju pertumbuhan. Hal ini berarti konselor melakukan pendampingan pastoral secara berkesinambungan dengan tujuan untuk membimbing konseli menjadi agen perubahan, baik untuk dirinya sendiri maupun lingkungan sekitarnya.

Mencapai pemahaman diri secara penuh dan utuh. Dengan pendampingan yang dilakukan konselor maka akan menolong konseli dalam memahami dirinya sendiri secara penuh dan utuh. Artinya, konseli dapat memahami akan apa yang menjadi kekuatan dan kelemahan yang ada dalam dirinya. Selain itu, konseli akan mampu melihat setiap kesempatan dan tantangan yang ada sehingga membuat pemahaman dirinya dan semakin percaya diri.

Belajar berkomunikasi yang lebih sehat. Pendampingan yang dilakukan oleh konselor akan menolong konseli dalam menciptakan atau melakukan komunikasi yang baik dan sehat terhadap lingkungannya. Konseli yang memiliki permasalahan hidup, terutama berhubungan dengan sosial, akan sangat sulit untuk berkomunikasi dengan baik dan sehat. Oleh karena itu diperlukan pendampingan untuk melatih konseli tersebut secara formal dan terstruktur.

Berlatih tingkah laku baru yang lebih sehat. Dengan adanya pendampingan pastoral yang dilakukan, akan menolong konseli dalam mengubah tingkah lakunya yang buruk menjadi lebih sehat. Konselor dapat memberikan arahan dan bimbingan kepada konseli untuk mulai berlatih dan membiasakan tingkah laku yang baru, sehingga dapat diterima oleh lingkungan sekitar. 
Belajar mengungkapkan diri secara penuh dan utuh. Pendampingan pastoral akan menolong konseli untuk memahami dan menjadi dirinya sendiri secara penuh dan utuh. Konselor dapat membina konseli untuk mengungkapkan dan mengekspresikan akan apa yang menjadi keinginan, perasaan dan harapannya kedepan secara utuh.

Dapat bertahan. Dengan melakukan pendampingan pastoral, konselor dapat menguatkan konseli dalam menghadapi setiap tantangan hidup yang baru. Konselor membimbing konseli untuk menerima setiap keadaan dengan lapang dada dan mengatur kehidupannya kembali dengan kondisi yang baru.

Menghilangkan gejala-gejala yang disfungsional. Dalam pendampingan pastoral yang dilakukan, konselor menolong konseli untuk menghilangkan atau menyembuhkan gejala-gejala yang mengganggu dan tidak sesuai dikarenakan masa krisis yang telah dialaminya.

\section{Pembinaan Narapidana}

Istilah narapidana merupakan penggabungan dari dua kata, yaitu "nara" dan "pidana". Ari Astuti mengutip penjelasan dari R.A. Koesnoen, kata "nara" tersebut berasal dari Bahasa sansekerta yang berarti kaum atau orang-orang; sedangkan kata “pidana” berasal dari bahasa Belanda, yaitu "Straf” (Astuti, 2011). Menurut Nawawi, narapidana adalah jenis sanksi pidana yang paling banyak ditetapkan dalam ketentuan KUHP (Ketentuan Undang-Undang Hukum Pidana), yang diteliti untuk membuat perumusan delik kejahatan (Barda Nawawi, 2010). Zainul Akhyar mengutip pendapat Simorangkir, menjelaskan bahwa narapidana adalah orang tahanan, orang yang ditahan di lembaga pemasyarakatan atau Rumah Tahanan Negara (Akhyar, Matnun, \& Najibuddin, 2014).

Dari beberapa penjelasan tersebut, peneliti menyimpulkan narapidana adalah seseorang atau sekelompok orang yang melakukan pelanggaran tindakan pidana sehingga mereka harus menerima konsekuensi yaitu kehilangan kemerdekaannya di dalam lembaga pemasyarakatan sesuai dengan peraturan yang sudah ditetapkan dalam Undang-Undang.

Seseorang bertindak melawan hukum selalu didasari oleh motivasi atau keinginan. Motivasi tersebut dibangun karena adanya dorongan dari faktor lingkungan yang membuat seseorang melakukan tindakan kriminal. Ada sepuluh macam kategori 
sosial budaya, yang menyebabkan seseorang melakukan tindakan kriminal, yaitu (Sahrina, 2011) :Tegangan antara tradisionalisme dan westernisme, tegangan karena kemunafikan/hiperitisme, tegangan karena kesenjangan informasi internal antar kota dan desa, antar pemimpin dan rakyat, antar si kaya dan si miskin, tegangan karena proses pengambilan keputusan yang cenderung otoriter, tegangan karena sistem pendidikan yang ambivalen, tegangan karena dikotomi pengembangan kewiraswastaan pribumi dan multi nasional coorperation serta non pribumi, tegangan karena menipisnya kesadaran untuk membela kaum, tegangan karena gaya hidup konsumerisme versus terbatasnya modal, tegangan karena tidak kestabilan harga produksi masyarakat kecil, dan tegangan karena ketidakeimbangan antara sektor-sektor ekonomi dan sektor non-ekonomi.

Bagi narapidana yang sudah selesai masa tahanannya di Lembaga Pemasyarakatan dan kembali ke lingkungan masyarakat luas, pada umumnya mereka menerima diskriminasi. Masyarakat meyakini bahwa setiap orang yang telah berbuat jahat, maka selamanya ia akan berbuat jahat yang berkepanjangan. Hal ini dapat mengakibatkan narapidana yang sudah bebas dari Lembaga Pemasyarakatan tersebut, tidak mendapatkan tempat dalam berbagai kegiatan sosial dan kembali lagi ke pekerjaan lamanya.

Untuk menghadapi permasalahan tersebut, Lembaga Pemasyarakatan berusaha memberikan pembinaan atau pembimbingan kepada narapidana agar ketika mereka bebas, dapat diterima dalam lingkungan masyarakat. Pembinaan atau pembimbingan yang diberikan berupa pembinaan atau pembimbingan keterampilan. Pembinaan atau pembimbingan keterampilan diberikan dengan tujuan setelah keluar dari Lembaga Pemasyarakatan narapidana dapat menjalani hidupnya dan diterima di tengah-tengah masyarakat dengan harapan tidak melakukan tindakan kriminal (Fitrianto, 2016).

Sebagai tahap eksekusi, lapas mempunyai kegiatan untuk melakukan pembinaan atau pembimbingan terhadap warga binaan narapidana; dimana kegiatan tersebut merupakan bagian akhir dari sistem pemidanaan dalam tata peradilan pidana (Asrmarawati, 2019.). Pembinaan atau pembimbingan yang dilakukan terhadap narapidana memiliki tujuan. Seperti yang dijelaskan oleh Laurensius Arliman dalam bukunya yang berjudul Hukum dan Kesadaran Masyarakat, pembinaan atau pembimbingan tersebut diberikan agar selama dan selesainya pembinaan atau 
pembimbingan, para narapidana dapat berhasil memantapkan kembali harga diri dan kepercayaan dirinya serta bersikap optimis akan masa depannya, dapat memperoleh pengetahuan, minimal keterampilan untuk bekal mampu hidup mandiri dan berpartisipasi dalam kegiatan pembangunan nasional, berhasil menjadi manusia yang patuh hukum yang tercermin pada sikap dan perilaku yang tertib, disiplin serta mampu menggalang rasa kesetiakawanan nasional, memiliki jiwa dan semangat pengabdian terhadap bangsa dan negara (Laurensius, 2015).

Lembaga Pemasyarakatan Salemba kelas IIA memberikan pembimbingan keterampilan kepada para narapidana. Yusner menjelaskan bahwa dalam melakukan pembinaan keterampilan, Lembaga Pemasyarakatan juga mengadakan PKBM (Pendidikan Kegiatan Belajar Mengajar) yang ditujukan untuk narapidana dengan berstatus sebagai pelajar; dan juga BLK (Balai Latihan Kerja) yang bersifat pelatihan atau kursus keterampilan, seperti perkebunan, perikanan, melukis, komputer, mekanik.

Pembimbingan keterampilan tersebut, diadakan setiap hari Senin-Jumat, pukul 09.00-11.00. Namun, ada beberapa narapidana yang dipaksa untuk mengikuti pembimbingan atau pembinaan keterampilan agar ketika selesai masa tahanannya, mereka sanggup bekerja di tempat kerja yang baru dan tidak kembali pada pekerjaannya yang lama.

\section{Kegiatan Pemberdayaan Narapidana Untuk Melawan Stigma Masyarakat}

Pembinaan sosial di Lembaga Pemasyarakatan Salemba IIA dilaksanakan dengan memberikan bekal beberapa keterampilan kepada narapidana. Dalam melaksanakan pembinaan keterampilan tersebut, Lembaga Pemasarakatan Salemba IIA mengadakan PKBM (Pendidikan Kegiatan Belajar Mengajar) dan BLK (Balai Latihan Kerja). PKBM tersebut diberikan kepada narapidana yang masih berstatus pelajar; sedangkan BLK diberikan kepada narapidana yang non-pelajar. Bentuk-bentuk pembinaan keterampilan yang diberikan, seperti: perkebunan, perikanan, melukis, kursus komputer, mekanik, dan sebagainya.

Yusner Simbolon, S.H. sangat menekankan para narapidana Kristen untuk mengikuti pembinaan keterampilan karena menjadi bekal atau modal penting ketika mereka sudah selesai masa tahanannya dan hidup kembali di tengah-tengah masyarakat. 
Meskipun sudah diarahkan oleh Yusner untuk mengikuti pembinaan keterampilan, narapidana Kristen yang menjadi narasumber menjelaskan kepada peneliti bahwa tidak ada yang mengikuti pembinaan keterampilan tersebut. Ada beberapa alasan yang diberikan ketika peneliti menanyakan kepada narapidana, mengapa tidak mengikuti pembinaan keterampilan. Mereka menjelaskan bahwa dua jenis pembinaan tersebut berjalan di jam yang sama, yaitu pembinaan spiritual dengan pembinaan keterampilan. Para narapidana Kristen lebih memilih untuk mengikuti pembinaan spiritual. Kedua, kurangnya jumlah sarana di kelas pembinaan keterampilan membuat mereka harus bergantian dalam mengikuti pembinaan tersebut per enam bulan. Ketiga, dari jenis-jenis pembinaan keterampilan yang disediakan, tidak ada yang sesuai dengan kemampuan yang dimiliki oleh beberapa narapidana.

Meskipun para narasumber tidak pernah mengikuti pembinaan keterampilan, namun mereka tetap memiliki perencanaan setelah selesai masa tahanan mereka. Dari beberapa mereka ada yang berencana untuk membuka toko kelontong, ada yang mau berwirausaha sesuai dengan keahlian atau keterampilan yang dimilikinya, ada yang ingin melanjutkan bisnis lamanya karena beberapa perlengkapan masih ada dirumahnya, dan ada juga yang menyatakan bahwa dia memiliki kerinduan untuk kuliah di STT karena ingin menjadi hamba Tuhan.

Setelah sekian lama mengikuti berbagai pembinaan, para narapidana yang akan selesai masa tahanannya masih memiliki kekuatiran atau ketakutan yang dirasakan. Ada beberapa hal yang mereka kuatirkan atau takutkan, yaitu pekerjaan apa yang harus dilakukannya; kedua, apakah nanti sanggup atau tidak dalam menghadapi godaan untuk kembali kepada pekerjaan yang lama; dan ketiga adalah apakah setiap pembelajaran atau pembinaan yang diberikan di Lembaga Pemasyarakatan IIA, masih bisa melakukannya atau tidak.

Hal tersebut menunjukkan bahwa lamanya pembinaan yang telah dilalui tidak memberikan sebuah jaminan bahwa mereka akan siap menghadapi kenyataan kehidupan setelah selesai masa tahanannya. Secara mental dan spiritual, para narapidana yang akan selesai masa tahanannya tidak mengalami permasalahan. Hal ini dibuktikan dengan adanya beberapa perubahan karakter yang mereka alami dan kemampuan meresponi keberadaan dirinya di Lembaga Pemasyarakatan sebagai cara Tuhan dalam membuat dirinya bertobat. Pembinaan keterampilan diberikan untuk menolong narapidana yang 
akan selesai masa tahanannya agar tidak mengalami diskriminasi dari masyarakat justru tidak memberikan pengaruh yang cukup signifikan. Hal ini dibuktikan dengan adanya rasa kekuatiran atau ketakutan dalam menghadapi berakhirnya masa tahanan. Dan penyebab dari ketakutan atau kekuatiran yang mereka alami adalah ketidaktahuan akan apa yang harus dilakukan atau dikerjakan untuk menyambung hidupnya. Namun, hal tersebut juga dipengaruhi oleh ketidakikutsertaan para narapidana terhadap pembinaan keterampilan yang diadakan karena jam berlangsung pembinaan keterampilan sama dengan pembinaan spiritual.

\section{Hasil Pemberdayaan Narapidana Untuk Melawan Stigma Masyarakat}

Diskriminasi dari masyarakat kepada mantan narapidana merupakan peristiwa yang umum. Hal ini dikarenakan masyarakat meyakini bahwa setiap orang yang telah berbuat jahat, maka selamanya ia akan berbuat jahat yang berkepanjangan. Hal ini dapat mengakibatkan narapidana yang sudah bebas dari Lembaga Pemasyarakatan tersebut, tidak mendapatkan tempat dalam berbagai kegiatan sosial dan kembali lagi ke pekerjaan lamanya.

Lembaga Pemasyarakatan harus berusaha memberikan pembinaan kepada narapidana agar ketika mereka bebas, dapat diterima dalam lingkungan masyarakat. Pembinaan yang diberikan berupa pembinaan keterampilan; dengan tujuan setelah keluar dari Lembaga Pemasyarakatan narapidana dapat menjalani hidupnya dan diterima di tengah-tengah masyarakat dengan harapan tidak melakukan tindakan kriminal (Fitrianto, 2016).

Pembinaan keterampilan diberikan agar narapidana tidak kembali ke pekerjaan lama mereka setelah bebas dari Lembaga Pemasyarakatan. Pembimbingan ini sangat penting karena pada umumnya persoalan ekonomi seperti kemiskinan, penggangguran, dan sebagainya merupakan stimulus utama bagi seseorang melakukan tindakan pidana atau kejahatan.

Pembimbingan atau penerimaan sosial di Lembaga Pemasyarakatan Salemba IIA dilaksanakan dengan memberikan bekal keterampilan kepada narapidana. Dalam melaksanakan pembinaan keterampilan tersebut, Lembaga Pemasarakatan Salemba IIA mengadakan PKBM (Pendidikan Kegiatan Belajar Mengajar) dan BLK (Balai Latihan Kerja). PKBM tersebut diberikan kepada narapidana yang masih berstatus pelajar; 
sedangkan BLK diberikan kepada narapidana yang non-pelajar. Bentuk-bentuk pembinaan keterampilan yang diberikan, seperti: perkebunan, perikanan, melukis, kursus komputer, mekanik, dan sebagainya.

Yusner Simbolon, S.H. sangat menekankan para narapidana Kristen untuk mengikuti pembinaan keterampilan karena menjadi bekal atau modal penting ketika mereka sudah selesai masa tahanannya dan hidup kembali di tengah-tengah masyarakat.

Meskipun sudah diarahkan oleh Pak Yusner untuk mengikuti pembinaan keterampilan, narapidana Kristen yang menjadi narasumber menjelaskan kepada peneliti bahwa tidak ada yang mengikuti pembinaan keterampilan tersebut. Ada beberapa alasan yang diberikan ketika peneliti menanyakan kepada narapidana, mengapa tidak mengikuti pembinaan keterampilan. Mereka menjelaskan bahwa dua jenis pembinaan tersebut berjalan di jam yang sama, yaitu pembinaan spiritual dengan pembinaan keterampilan. Para narapidana Kristen lebih memilih untuk mengikuti pembinaan spiritual. Kedua, kurangnya jumlah sarana di kelas pembinaan keterampilan membuat mereka harus bergantian dalam mengikuti pembinaan tersebut per enam bulan. Ketiga, dari jenis-jenis pembinaan keterampilan yang disediakan, tidak ada yang sesuai dengan kemampuan yang dimiliki oleh beberapa narapidana.

Meskipun para narasumber tidak pernah mengikuti pembinaan keterampilan, namun mereka tetap memiliki perencanaan setelah selesai masa tahanan mereka. Dari beberapa mereka ada yang berencana untuk membuka toko kelontong, ada yang mau berwirausaha sesuai dengan keahlian atau keterampilan yang dimilikinya, ada yang ingin melanjutkan bisnis lamanya karena beberapa perlengkapan masih ada dirumahnya, dan ada juga yang menyatakan bahwa dia memiliki kerinduan untuk kuliah di STT karena ingin menjadi hamba Tuhan.

Setelah sekian lama mengikuti berbagai pembinaan, para narapidana yang akan selesai masa tahanannya masih memiliki kekuatiran atau ketakutan yang dirasakan. Ada beberapa hal yang mereka kuatirkan atau takutkan, yaitu pekerjaan apa yang harus dilakukannya; kedua, apakah nanti sanggup atau tidak dalam menghadapi godaan untuk kembali kepada pekerjaan yang lama; dan ketiga adalah apakah setiap pembelajaran atau pembinaan yang diberikan di Lembaga Pemasyarakatan IIA, masih bisa melakukannya atau tidak. 


\section{SIMPULAN}

Dari penelitian yang telah dilakukan, peneliti menemukan bahwa pembinaan keterampilan yang diberikan belum cukup membantu para narapidana yang akan selesai masa tahanannya, untuk siap menghadapi tantangan kehidupan di luar Lembaga Pemasyarakatan. Hal ini dibuktikan dengan adanya kekuatiran atau ketakutan yang masih dimiliki oleh para narapidana yang akan selesai masa tahanannya. Kekuatiran atau ketakutan yang dialami, seperti apa yang harus dilakukan setelah keluar dari Lembaga Pemasyarakatan nanti, sanggup atau tidaknya dalam menghadapi godaan untuk kembali pada pekerjaan yang lama, dan apakah setiap pembimbingan atau pembinaan yang telah diberikan masih dapat dilakukan atau tidak.

Hal ketidakikut sertaan para narapidana dalam pembimbingan atau pembinaan keterampilan dikarenakan jam berlangsungnya pembimbingan atau pembinaan keterampilan dengan pembimbingan spiritual dan kurangnya fasilitas yang ada untuk mendukung kegiatan pembimbingan tersebut. Karena kurangnya fasilitas tersebut, membuat para narapidana yang mau mengikuti pembimbingan atau pembinaan keterampilan tersebut harus bergantian per enam bulan sekali. Hal ini menyebabkan minat atau semangat dari narapidana menjadi berkurang, sehingga lebih memilih untuk mengikuti pembimbingan kerohanian.

\section{DAFTAR PUSTAKA}

Akhyar, Z., Matnun, H., \& Najibuddin, M. (2014). Persepsi Masyarakat Terhadap Mantan Narapidana di Desa Benua Jingah Kecamatan Barabai Kabupaten Hulu Sungai Tengah. Jurnal Pendidikan Kewarganegaraan, (Mantan Narapidana), 545557.

Asrmarawati, T. (n.d.). Pidana dan Pembinaan Dalam Sistem Hukum di Indonesia. Yogyakarta: Deepublish.

Astuti, A. (2011). Pembinaan Mental Narapidana di Lembaga Pemasyarakatan

Wirogunan Yogyakarta. Citizenship, (Pembinaan Mental Narapidana), 29-45. Barda Nawawi, A. (2010). Kebijakan Legislatif Dalam Penanggulangan Kejahatan Dengan Pidana Penjara. Yogyakarta: Genta Publishing.

Clebsch, W. A., \& Jaekle, C. R. (1994). Pastoral Care in Historical Perspective. New 
Tork: Rowman and Littlefield Publisher.

Engel. (2016). Pastoral dan Kebutuhan Dasar Konseling. Jakarta: BPK Gunung Mulia.

Fitrianto, H. (2016). Pola Pemberdayaan Narapidana. Jurnal Equilibrium,

(Pemberdayaan Narapidana), 242-250.

Hendri Wijayatsih. (2011). Pendampingan dan Konseling Pastoral. Gema Teologi.

Laurensius, A. S. (2015). Penegakan Hukum dan Kesadaran Masyarakat. Yogyakarta:

Deepublish.

Mawardi, D. R. (2015). Fungsi Hukum dalam Kehidupan Masyarakat. Jurnal MasalahMasalah Hukum, (Fungsi hukum), 271-283.

Nugroho, F. J. (2017). Pendampingan Pastoral Holistik: Sebuah Usulan Konseptual Pembinaan Warga Gereja. Evangelikal: Jurnal Teologi Injili Dan Pembinaan

Warga Jemaat. https://doi.org/10.46445/ejti.v1i2.71

Sahrina. (2011). Dampak Pembinaan atau Pembimbingan Keagamaan Terhadap

Narapidana di Lembaga Pemasyarakatan Kabupaten Takalar. Universitas Islam Negeri.

Sanusi, A. (2019). Evaluasi Pelaksanaan Pembinaan Narapidana di Lembaga

Pemasyarakatan Terbuka. Jurnal Ilmiah Kebijakan Hukum.

https://doi.org/10.30641/kebijakan.2019.v13.123-138

Sriulina, I. (2017). Pendampingan Pastoral yang Memberdayakan Penyintas Sinabung yang Mengalami Trauma. Indonesian Journal of Theology.

https://doi.org/10.46567/ijt.v4i2.40

Van, B. (2017). Pendampingan Pastoral. Jakarta: BPK Gunung Mulia.

Wiryasaputra, T. S., \& Handayani, R. (2012). Pengantar Konseling Pastoral. Asosiasi Konselor Pastoral Indonesia, 79-86.

Zaluchu, S. E. (2020). Strategi Penelitian Kualitatif dan Kuantitatif Di Dalam Penelitian Agama. Evangelikal: Jurnal Teologi Injili Dan Pembinaan Warga Jemaat, 4(1), 28. https://doi.org/10.46445/ejti.v4i1.167 